AperTO - Archivio Istituzionale Open Access dell'Università di Torino

\title{
Assessing the effect of fire severity on sediment connectivity in central Chile
}

\section{This is a pre print version of the following article:}

Original Citation:

\section{Availability:}

This version is available http://hdl.handle.net/2318/1765590

since 2021-01-01T19:05:06Z

Published version:

DOI:10.1016/j.scitotenv.2020.139006

Terms of use:

Open Access

Anyone can freely access the full text of works made available as "Open Access". Works made available under a Creative Commons license can be used according to the terms and conditions of said license. Use of all other works requires consent of the right holder (author or publisher) if not exempted from copyright protection by the applicable law. 


\section{IIIS AperTO}

UNIVERSITÀ

DEGLI STUDI

DI TORINO

This is the author's final version of the contribution published as:

[Lorenzo Martini, Lorenzo Faes, Lorenzo Picco, Andrés Iroumé, Emanuele Lingua, Matteo Garbarino, Marco Cavalli, Assessing the effect of fire severity on sediment connectivity in central Chile, Science of The Total Environment, 728:2020,139006, https://doi.org/10.1016/j.scitotenv.2020.139006]

The publisher's version is available at:

[https://www.sciencedirect.com/science/article/abs/pii/S0048969720325237]

When citing, please refer to the published version.

Link to this full text:

[http://hdl.handle.net/2318/1765590] 


\title{
Assessing the effect of fire severity on sediment connectivity at the catchment scale
}

\author{
Lorenzo Martini (a), Lorenzo Faes (a), Lorenzo Picco (a,b,c), Marco Cavalli (d), Emanuele Lingua (a), Matteo \\ Garbarino (e), Andrés Iroumé (f)
}

\begin{abstract}
(a) University of Padova, Department of Land, Environment, Agriculture and Forestry, Legnaro, Italy.
(b) Universidad Austral de Chile, Faculty of Engineering, Valdivia, Chile

(c) Universidad Austral de Chile, RINA - Natural and Anthropogenic Risks Research Center, Valdivia, Chile

(d) National Research Council, Research Institute for Geo-Hydrological Protection, Padova, Italy

(e) University of Torino, Department of Agricultural, Forest and Food Sciences, Grugliasco, Italy

(f) Universidad Austral de Chile, Faculty of Forest Sciences and Natural Resources, Valdivia, Chile
\end{abstract}

Corresponding author: Iorenzo.martini.2@phd.unipd.it, Department of Land, Environment, Agriculture and Forestry, Università degli Studi di Padova, Viale dell'Università 16, 35020 Legnaro (PD), Italy.

1 Keywords: sediment connectivity, wildfire, fire severity, natural disturbance, Rio Toro, Chile.

\section{ABSTRACT}

4 Chilean territory is permanently affected by severe wildfires, which drastically reduce the forest cover and promote water runoff, soil erosion, sediment yields and slope instabilities. To understand how the geomorphic system responds to wildfires in terms of sediment dynamics, the assessment of sediment connectivity, i.e. the property describing the relationships between compartments of a geomorphic system, is crucial. This study aims to quantify the spatial linkages between fire severity and sediment connectivity to identify common patterns and driving factors. The compound use of field data and open-source satellite imagery helped to apply the Relative differenced Normalized Burn Ratio (RdNBR) and the Index of Connectivity (IC) in the context of two consecutive wildfires (occurred in 2002 and 2015) in the Rio Toro catchment (Chile).-The fire severity assessment showed that the 2002 event affected $90 \%$ of the catchment, with high severity areas representing around $70 \%$. The 2015 wildfire instead, affected $76 \%$ of the catchment with moderate severity around $42 \%$. Accordingly, the IC increased after both wildfires, as a result of the sudden reduction in forest cover in severely affected areas. However, only for the second disturbance, it was possible to observe a 
clear relationship between the RdNBR and the IC variations. The different degree of vegetation cover heterogeneity between the two pre-wildfire scenarios contributed to different fire severity and IC variability between the two disturbances. The use of open-source data and the development of a weighting factor (W), to be used in IC, able to capture the land cover change driven by the wildfires, could make it straightforward the application of this approach promoting its reproducibility in other catchments for land management and risk mitigation purposes.

\section{INTRODUCTION}

Landscape configuration is determined by the interaction of natural disturbances, geomorphic processes and landforms expressed at multiple spatial and temporal scales. Wildfires are recognized as major agents of land and soil degradation (Shakesby, 2011) and geomorphological changes in densely vegetated landscapes (Neary et al., 2005). In burned catchments, the interaction among vegetation, fire severity and hydrogeomorphic components needs to be deeply investigated to understand the variety of observed responses. The high amount of burned material (e.g., charcoal and ashes) deposited on the soil surface can modify soil properties by increasing or reducing soil infiltration capacity depending on the time since fire (Woods and Balfour, 2008; Shakesby, 2011) (Swanson, 1981; Certini, 2005; Shakesby and Doerr, 2006; Larsen et al., 2009). Therefore, the alteration of soil properties often leads to the increase of water runoff, exacerbation of soil erosion and, eventually, higher production of sediment yield, which can be detected even at a long-term scale (Benavides-Solorio and MacDonald, 2001; Neary et al., 2005). Furthermore, the-fire effects are different in terms of hydrological (e.g. overland flow generation) and erosional (e.g. sediment loss) responses. As stated by Vieira et al. (2015) in fact, the latter is more evident because of the role played by the changes in soil aggregate stability and organic matter content, which indirectly favors erosive capacity of the runoff. Direct effects on river systems have been documented concerning the increase of in-channel wood recruitment (Benda and Sias, 2003), the alteration of channel stability (e.g. channel aggradation, DeBano et al., 1998), the speed of vegetation recovery and the rapid relocation of the channel heads along the hillslopes (Wohl and Scott, 2017). Indirect effects mainly concern the alteration of annual water yields (Hallema et al., 2019) and hillslope instabilities given the higher occurrence of landslides and debris flows (Neary, 2005). 
43 Many classification systems and change detection methods of multispectral data, based on satellite imagery, 44 such the Relative differenced Normalized Burn Ratio (Miller and Thode, 2007), have been adopted to map 45 and measure the overall effect of fire on vegetation and surficial soil, i.e. burn severity (DeBano et al., 1998). 46 It is widely recognized that this overall effect strongly depends on the fire intensity, duration and pre-fire disturbance history, which determines variable sensitivity across the landscape and over time (Brogan et al., 48 2019). Further intrinsic factors such as the area, topography, vegetation, geology and climate, affect the magnitude of changes caused by the natural disturbance (Swanson, 1981). Notably, topography shows strong relationships with fire severity because it influences biophysical gradients (e.g., moisture, solar radiation) and characteristics of the fuel. For instance, upper slope positions locations and steep slopes are typically increasing the pre-heat of fuels, whereas different orientations cause high variability in fuel's drying out (Iniguez et al., 2008; Carmo et al., 2011).

In this context, the assessment of fire severity, which often encompasses the properties of intensity and duration, is essential to quantify the fire-related impact. The determination of fire severity and related impacts would help to: i) protect sensitive ecosystems from reduction of soil organic matter, modification of population dynamics and roots failure; ii) to safeguard local forest and water users from the reduction of forest productivity and touristic value, and from the sudden release of chemicals into the stream network; iii) to prevent economic losses for downstream areas caused by mass failure and floods (Neary et al., 2005). Framing the response of an entire catchment to natural disturbances in terms of variation of sediment supply, routing and deposition is still a controversial issue due to the variety of factors involved (e.g., disturbance properties, sediment characteristics, topography, land cover, hydrological regime). In post-wildfire conditions, if a great amount of sediment is available for sudden mobilization, the awareness of how a catchment facilitates the transfer of sediment between source areas and channel network is vital to predict future scenarios and reduce the associated risk (Mazzorana et al., 2019). To this end, the geomorphic property known as connectivity (Wohl et al., 2019) is gaining interest from the scientific community especially concerning major disturbances. Specifically, sediment connectivity underlies the sediment transfer between the compartments of a geomorphic system and their relationships, which control the sediment cascade and geomorphic response to disturbance events (Bracken and Crooke, 2007; Fryirs, 2013). Several metrics of sediment connectivity have been proposed to overcome the more traditional field measurement and to exploit 
the high amount of topographic data available nowadays (Heckmann et al., 2018). Following this trend, the topography-based Index of Connectivity (hereinafter IC), proposed by Borselli et al. (2008) and refined by Cavalli et al. (2013) has become a solid and accessible instrument to assess the degree of linkage between sources and sinks of sediment in various contexts. Therefore, many authors grasped the opportunity to map sediment connectivity using the IC in different environments and considering plenty of numerical approaches: Gay et al. (2016) and Kalantari et al. (2017), mapped connectivity in lowlands by integrating catchment infiltration/runoff properties and precipitation-runoff variability, respectively; López-Vicente and Ben-Salem (2019) developed a new aggregated index based on the RUSLE2 equation; Rainato et al. (2018) analyzed the (de)coupling relationships of a small dolomitic catchment.

Mapping the IC with respect to major natural disturbances is becoming paramount to understand the variation of sediment connectivity's spatial patterns, their evolution and to predict downstream adjustments (Cavalli et al., 2019). In post-disturbance scenarios, sensitivity is defined as the rate of response to the change, so that highly connected systems tend to respond faster than less-connected ones (Brunsden and Thornes, 1979). Geomorphic systems affected by volcanic eruptions (Martini et al., 2019), land-use change (Persichillo et al., 2018; Llena et al., 2019), typhoons and monsoons (Chartin et al., 2017; Singh and Sinha, 2019), and wildfires (Williams et al., 2016; Estrany et al., 2019; Ortíz-Rodríguez et al., 2019) are closely monitored for their sensitivity in terms of sediment connectivity. However, still strong efforts need to be made to standardize a process to consider the land cover change and its effect on the IC to make such an accessible tool fully applicable. In other terms, is it possible to convey the essential information about land cover changes into a single parameter, such as the Index of Connectivity, to explain or predict catchment-scale responses to natural disturbances? To address this question, multi-disciplinary approaches are indeed required to consider different phenomena from different standpoints and to support useful catchment management decisions. Accordingly, the present study aims at defining how multiple wildfires interact with catchment-scale sediment connectivity by analysing fire severity and sediment connectivity spatial patterns and by identifying common driving factors and interlinked relations in an Andean catchment. The general objectives of the work are to improve awareness about the fire-related impacts from a multidisciplinary perspective, by linking the ecological and geomorphic response and to provide a methodological approach to prioritize areas of hillslope instabilities in wildfire-affected river basins. The specific objectives are: 
99 i) to investigate interlinked relationship between fire severity and sediment connectivity changes induced by 100 wildfires;

101 ii) to move towards the standardization of a procedure to apply the IC after major disturbances;

102

iii) to rely upon open source data so the application of the proposed methodology could be replicated in other contexts.

The study area is the Rio Toro catchment, located in Chile (Fig. 1a), close to the north-eastern border of the Araucanía Region (IX Región) (Fig. 1b) and affected by two wildfires in 2002 and 2015. The area extends for $18 \mathrm{~km}^{2}$, entirely inside the Malleco National Reserve, with elevation ranging from 760 to $1810 \mathrm{~m}$ a.s.l. and a mean slope of $24^{\circ}$. The climate is classified as temperate warm humid (Fuenzalida, 1965), strongly influenced by the presence of the Andean Cordillera (E) and the Pacific Ocean (W). The average annual precipitation is about $2480 \mathrm{~mm}$ (Comiti et al., 2008), with a monthly maximum and minimum of $490 \mathrm{~mm}$ and $62 \mathrm{~mm}$ in June and January, respectively (average rainfall calculated for the period 2000-2018; source:http://explorador.cr2.cl/). Bedrock layer is primarily composed of pyroclastic rocks generated by the high volcanic activity of the Southern Andes volcanic Zone (SVZ, $\left.33^{\circ} \mathrm{S}-46^{\circ} \mathrm{S}\right)$ and triggered by the NazcaSouth America plate convergence (Cembrano and Lara, 2009). The Rio Toro channel network, which features a pluvial/nival hydrological regime (Comiti et al., 2008), develops mainly with south-north direction with a total length of $11 \mathrm{~km}$ from the upstream ridges to the downstream Rio Niblinto, where the outlet of the study catchment is established (Fig. 1c). The main channel, receiving water from two branches divided by the central ridge, is classified as a third-order stream featuring a step-pool / cascade bed morphology with a mean channel slope of $0.05 \mathrm{~m} / \mathrm{m}$ (Comiti et al., 2008; Iroumé et al., 2015; Picco et al., in review). The forest is mainly composed of endemic species of Araucaria araucana and Nothofagus spp. (southern beech). The two species naturally form mixed forests along the Andes Cordillera in the South-Central Chile and western

124 Argentina (Veblen et al., 1982). The understorey of Araucaria-Nothofagus forests hosts Chusquea spp. (quila), a fast-growing bamboo plant reaching high densities, especially after major natural disturbances that 
typically affect this type of landscape (Gunckel et al., 1948; Veblen et al., 1981). Until 2002, when the first wildfire occurred, the Rio Toro catchment was almost completely covered by forests. At lower elevation (below 1200 m.a.s.I.) the main species were Nothofagus dombeyi and N. nervosa while Araucaria araucana stands dominated the landscape above 1200-1300 m a.s.l. The 2002 fire, occurred in late February, affected both the Malleco National Reserve and the near Tolhuaca National Park, with an overall burned area of about 11660 ha (Assal et al., 2018), greatly contributing to the 20000 ha burned in the region in the summer fire season (González et al., 2005). Besides, during the fire season of 2014-15, which counted 1344 wildfires and almost 46000 ha burned in the Araucanía Region alone (CONAF, 2019), another wildfire affected the same area in late February 2015.

In central Chile, land use practices and extreme climatic conditions are exacerbating wildfires effects (Bowman et al., 2019). For this reason, there is growing interest in monitoring future developments for this and similar areas, where slope instabilities could be expected. Even though no instabilities were reported recorded by other studies after the 2002 wildfire (Comiti et al., 2008; Iroumé et al., 2015), the re-occurrence of the 2015 event may have increased their likelihood.

\section{MATERIAL AND METHODS}

The present study was carried out following a methodological workflow with two parallel phases regarding (i) the assessment of severity of the two wildfires occurred in 2002 and 2015, and (ii) the mapping of sediment connectivity changes following the aforementioned events (Fig. 2). The development of both activities relies upon field data, acquired during field campaigns carried out in 2019, and freely available satellite Landsat data provided by open-source websites. 
154 The need for multi-temporal images and consistency among the two methodological phases drove the attention towards Landsat missions, which offer long time series and sufficient global coverage at $30 \mathrm{~m}$ resolution (Banskota et al., 2014). Two Landsat 7 ETM+ images corresponding to periods pre- and post2002 wildfire (01/02/2002, 20/02/2003) and two Landsat 8 OLI images corresponding to the pre- and post2015 wildfire $(28 / 01 / 2015,31 / 01 / 2016)$ periods were selected from the U.S. Geological Service free satellite provider EarthExplorer (EarthExplorer, 2019). After the selection, Landsat products were ordered and obtained from the Earth Resources Observation and Science Center (EROS) Science Processing Architecture On Demand Interface (ESPA). The ESPA allows the processing of Landsat data beyond the standard Landsat Level-1 processing level (ESPA, 2018). Therefore, the four images were provided atmospherically corrected at surface reflectance to account for sensor, solar and atmosphere distortion (Young et al., 2017). In addition, we applied transformations to guarantee continuity among the Landsat 7 ETM+ and Landsat 8 OLI bands and avoid misinterpretations in the outcomes (Roy et al. 2016).

The topographic information required for developing the sediment connectivity analysis is represented by the Global Digital Elevation Model (DEM) with a spatial resolution of $12.5 \times 12.5 \mathrm{~m}$ cell size derived by the ALOS PALSAR satellite imagery system. The data were processed and redistributed by the Alaska Facility Service (ASF, 2019; dataset: ASF DAAC, 2009), which provides Radiometrically Terrain-Corrected (RTC) products. Detailed information about the accuracy of ASF's products can be found in Gesch et al. (2014).

\subsection{Field data}

During January 2019, multiple field campaigns were carried out in the Rio Toro catchment to collect land cover data. We established a total of 106 square sampling plots of about $400 \mathrm{~m}^{2}$, in which the percentage of area covered by understorey, bare soil and rocks, grassland, deadwood (standing and/or lying on the ground)and trees was visually determined (Fig. 3). In particular, the understorey was defined as the vegetation layer including bamboo, Araucaria and Nothofagus seedlings and shrubs developing under the trees. The latter category instead, includes only living trees taller than $1.30 \mathrm{~m}$.

180 In addition, we also evaluated specific ground characteristics on a subset of 46 sampling plots regarding the number of standing dead and living trees and the number of obstructions on the ground (Table S1). The 
distribution of the plots within the study catchment was highly constrained by the scarce accessibility due to steep slopes, lack of roads and presence of fallen logs. The position of each sampling plot was taken measuring the centroid using a GPS Trimble Juno 5.

\#\#\# FIGURE 3 \#\#\#

\subsection{Fire severity assessment}

Using the multispectral satellite data described in the section 3.1, we first calculated the Normalized Burn Ratio (NBR) for each pre- and post-wildfire year $(2002,2003 ; 2015,2016)$ according to the following formula:

$$
N B R=\frac{N I R-S W I R 2}{N I R+S W I R 2}(1)
$$

where, NIR is the Near InfraRed band and SWIR2 is the ShortWave InfraRed band, which are the two wavelengths most sensitive to wildfires (Key and Benson, 2006). In order to provide a quantitative measure of change, the NBR calculated after the fire was subtracted from the NBR calculated before the fire. The resulting delta NBR (dNBR) was calculated as follows:

$$
d N B R=\left(\left(N B R_{\text {prefire }}-N B R_{\text {postfire }}\right) * 1000\right)-d N B R_{\text {offset }}(2)
$$

where, the dNBR is conventionally scaled up by a factor of 1000 to obtain an integer output (Miller et al.,

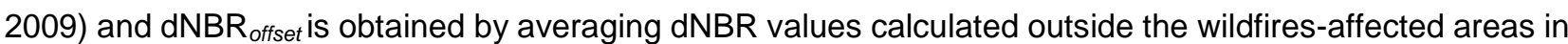
order to avoid reflectance biases given by the natural phenological effect (Parks, et al., 2014; Morresi et al. 2019). Given the occurrence of two wildfires in the Rio Toro catchment, multiple dNBRs were calculated as 
the difference between the years 2003-2002; 2016-2015 and 2016-2002. The latter aims at detecting the spectral changes given by the sum of the two wildfires and it has been considered only as a proxy variable

210 in the function used to classify the severity of the two separate wildfires.

211 Furthermore, to improve the accuracy of wildfire severity assessment we calculated the Relative dNBR 212 (RdNBR), following equation 3:

$$
R d N B R=\frac{d N B R}{\sqrt{\left|N B R_{\text {prefire }}\right|}}(3)
$$

where the absolute sign in the denominator avoids unreal numbers as results.

217 Choosing the relative ratio (RdNBR) instead of the absolute one (dNBR) permits to increase enhance the classification accuracy for high severity categories especially in more heterogeneous environments and to compare fires across time and spatial scales (Miller and Thode, 2007). The resulting three RdNBR maps (2002-2003, 2015-2016 and 2002-2016) were then classified using field data. From the sampling plots, we tested the combination of field metrics that best fitted with RdNBR values corresponding to the period 2002-2016, which summarizes all the changes in reflectance caused by both wildfires. The ratio between areas of bare ground and bare ground plus tree cover area (hereinafter defined as Severity Factor, SF) reported the strongest relationship with RdNBR values, according to a second-order polynomial function $\left(R^{2}=0.65\right)$. Using the natural breaks algorithm, the SF was grouped into four classes corresponding to unburned (or negligible severity), low, moderate and high severity. Using the polynomial function it was possible to carry out the four RdNBR classes' thresholds, which determine the classification scheme used in the wildfire severity maps 2002-2003 and 2015-2016 (Fig. S1). The classification accuracy calculated between measured and predicted severity of sampling plots was $62 \%$ with a Cohen's Kappa coefficient $(\mathrm{K})$ of 0.45 , indicating moderate agreement between the raters. The final wildfire severity maps were then compared in terms of spatial patterns, with particular focus on the eventual changes or similarities among different severity areas between the two events. Similarity analysis 
234 (e.g. unburned 2002 - unburned 2015). On the contrary, the variation was evaluated through the transition matrix (or cross-tabulation matrix), to highlight gains or losses among the classes.

236 To improve awareness on how the topographic features of the Rio Toro affected the fire severity in the two events, two Generalized Linear Models (GLMs) were carried out. The effect of slope, elevation (continuous), slope position (Guisan et al., 1999), aspect (categorical) were tested on the RdNBR. We applied simple random sampling with a $95 \%$ confidence interval to select the most appropriate number of samples to be used in the GLMs.

\subsection{Mapping sediment connectivity}

The analysis of sediment connectivity was performed through the Index of Connectivity, applied to four periods corresponding to 2002, 2003, 2015 and 2016. The IC in the Rio Toro catchment was computed using the open-source, stand-alone software SedlnConnect 2.3 (Crema and Cavalli, 2018), which operates using TauDEM tool for hydrological functions (Tarboton, 1997). Following the original formula by Borselli et al. (2008), the IC relies upon two components that describe the linking relationships between sediment sources and downstream areas, so:

250

251

$$
I C=\log _{10}\left(\frac{D_{u p}}{D_{d n}}\right)=\log _{10}\left(\frac{\bar{W} \bar{S} \sqrt{A}}{\sum_{i} \frac{d_{i}}{S_{i} W_{i}}}\right)
$$

where, $D_{\text {up }}$ is the upslope component representing the potential for downward routing of the sediment according to the catchment's upslope area features. Hence, $\bar{W}$ and $\bar{S}$ are the average value of the impedance to sediment fluxes and the average slope $(\mathrm{m} / \mathrm{m})$ in the upslope catchment, is respectively and $A$ is the contributing area $\left(\mathrm{m}^{2}\right)$ of the specific point under investigation. On the denominator, $D_{d n}$ is the downslope component including the characteristics that could affect the transfer of sediment: $d_{i}$ is the length $(\mathrm{m})$ of the 258 flow path along the $i^{\text {th }}$ cell, $W_{i}$ is the weighting factor and $S_{i}$ the slope gradient of the $i^{\text {th }}$ cell. 
259 In the present study, we made use of a unique DEM as the main source of topographic information for the computation of the IC for the four wildfire scenarios. This choice was constrained by the lack of representative DEMs for the two events and by the assumption that no major morphological changes, detectable at $12.5 \mathrm{~m}$ resolution, occurred during the period between the two wildfires. On the contrary, an adaptive weighting factor has been developed to represents the differences of impedance to sediment fluxes likely to be caused by the large variability in land cover due to the wildfires.

Finally, to highlight the linkages between hillslopes and the Rio Toro (i.e. lateral connectivity of the system), we set the whole stream network as target of the IC computation.

\subsubsection{Weighting factor}

To derive the weighting factor for the IC, the Manning's $n$ for the overland flow was selected original USLE C-factor (Wischmeier and Smith, 1978) and its variants (see Chartin et al., 2017; Lizaga et al., 2017; LópezVicente and Ben-Salem, 2019) since we consider it a better proxy of sediment impedance in natural catchments. Following the additive method provided by Arcement and Schneider (1989), an ad-hoc Manning's coefficient was computed for each of the 46 sub-sampling plots according to the ground characteristics collected during field campaigns and described in the section 3.2.

From the plot-derived Manning's $n$, a new approach has been adopted, based on the abrupt land cover changes at the pixel scale, in order to produce four catchment-scale weighting factor maps. The four W factor maps (hereinafter $\mathrm{W}$ factor maps) were generated starting from the correlation between the Manning's $n$ and the spectral vegetation index known as Integrated Forest Z-score (IFZ) calculated from the four Landsat images (eq. 5). The IFZ is a threshold-based index aiming at identifying the likelihood of a pixel to be not forested so that it represents a strong index to track vegetation changes and recovery after wildfires (Huang

$$
I F Z=\sqrt{\frac{1}{N B} \sum_{i=1}^{N}\left(\frac{b_{i}-\bar{b}_{i}}{S D_{i}}\right)^{2}}
$$


Where, NB is the number of spectral bands employed (in this work SWIR and SWIR2) $b_{i}$ is the spectral value

of the pixel of band $i, \bar{b}_{i}$ and $S D_{i}$ are respectively the mean and standard deviation of random pixel samples of the band $i$. Hence, the IFZ and Manning's $n$ are inversely related: higher is the chance for a pixel to be not forested and lower is the impedance to sediment fluxes. More information about the fitting model IFZManning's $n$ are present in the supplementary material (Fig. S2).

Although similar approaches, combining land use-based roughness and spectral indexes, have been proposed in the field of connectivity (e.g. Mishra et al., 2019), they mainly focused on the use of Normalized

Difference Vegetation Index (NDVI) that is less sensitive to the sudden changes in reflectance than the IFZ (Huang et al., 2010; Chu, et al., 2016; Morresi et al., 2019). Once the Manning's $n$ was extended for the whole catchment and the four periods, the final weighting factor maps (W) were generated following the normalization equation originally proposed by Trevisani and Cavalli (2016) for the topographic roughness:

$$
W=1-\frac{\ln (n)-\ln \left(n_{\min }\right)}{\ln \left(n_{\max }\right)-\ln \left(n_{\min }\right)}(6)
$$

where $n_{\min }$ and $n_{\max }$ are the minimum and maximum Manning's coefficients included within the range 0.001 1 and converted in the logarithmic form. The main advantages of this operation are: i) to preserve the adimensionality of IC, as also stressed by Zanandrea et al. (2020), ii) to offer a wider range of W factor values, otherwise constrained by the additive method of Arcement and Schneider (1989), and allowing an enhancement of the spatial variability in the final IC maps and iii) to move towards the full standardization of land use-based W factor. In the present work, differences among datasets were analysed for their statistical significance using the nonparametric Kruskal-Wallis (KW) test; the comparisons were considered statistically significant if $\mathrm{P}<0.001$ (given the high statistical power from the high number of pixels). All statistical procedures were carried out with the support of Rstudio version 1.2.5019 (Rstudio Team, 2016) and Statgraphics 18. 
Two severity maps based on RdNBR classification for 2002 (Fig. 4) and 2015 (Fig. 5) wildfires in the Rio Toro catchment are presented. After the 2002 event, significant burned areas covered 1657 ha, which corresponds to the $90.9 \%$ of the whole study catchment basin. Particularly, high severity represents the most widespread class, occupying $68.9 \%$, whereas moderate and low severity classes characterize $14.7 \%$ and $7.3 \%$ of the study area, respectively. On the contrary, the area classified as unburned covers $9.1 \%$ of the catchment area and it is mainly located in the further upstream and downstream positions. The 2015 fire severity map shows 1384 ha of burned areas (75.8\%), with the prevalence of moderate severity areas, covering the $42.2 \%$ of the total study catchment. Less represented are the high and low severity patches, which covers $23.4 \%$ and $10.2 \%$ of the total area, respectively. The map shows a major presence of high severity areas, mainly located on the left slopes facing North-East and, conversely, moderate and low severity spread along the right slope, facing South-West. Still, the areas unaffected by the fire can be found at lower and upper elevations as well as in the higher and steeper ridges on the right slope. However, unburned areas are the second most represented class with $24.1 \%$.

Despite the major difference in high severity areas, similar patterns can be observed in the two maps: unburned areas near the northern and southern borders; high and moderate areas in the central part. The Jaccard Index, calculated using the intersection and union of the same fire severity areas in \% for the two wildfires, demonstrates poor similarity in the overlap for the low and moderate severity classes, with outcomes of 0.06 and 0.12 , respectively. The higher similarity was found for the extreme classes with outcomes of 0.30 (High severity) and 0.35 (Unburned). The comparison between the 2002 and 2015 fire severity maps led to the development of the transition matrix (Table 1), which points out the percentage of catchment within each combination of severity classes as well as the total for each period. Diagonal entries 
show the percentage of severity that did not change throughout the years, suggesting that highly burned

$341(21.4 \%)$ and unburned (8.7\%) areas are the ones that persisted the most after the events. On the other hand, 342 low (1.1\%) and moderate (6.5\%) severity areas are the classes that show lower persistence and therefore 343 higher changes. The gain and losses from 2002 to 2015, exhibits that moderate severity class gained the $34435.8 \%$ of the catchment, whereas high severity class lost the $47.6 \%$ of the catchment. Lowest gains were 345 experienced by the low severity class, $9.1 \%$ of the landscape, whereas lowest losses were experienced by 346 the unburned class.

\section{\#\#\# TABLE 1 \#\#\#}

The results of the GLMs showed that RdNBR values are statistically related to slope, aspect ( $p$-value $<0.001)$ and slope position $(p$-value $<0.05)$ variables in both wildfires. On the contrary, elevation did not show statistical correlation with fire severity $(p$-value $>0.05)$ in the first wildfire, whereas in the second one did (Table 2). Since slope position is derived from the combination of slope and elevation, it showed a weaker but still significant correlation with fire severity in both cases. Besides, the analysis regarding the combined effect of the two categorical variables (slope position and aspect) gave negative results due to nonsignificance $(p$-value $>0.05)$.

357

\#\#\# TABLE 2 \#\#\#

\subsection{Sediment connectivity}

Peculiar spatial patterns can be observed in the IC maps (Fig. 6). In 2002, high IC areas were located mainly on the left slopes and stream banks, whereas low IC values characterize the small sub-catchment close to 364 the outlet, as well as the high and flat areas along the southern border (Fig. 6A). Following the 2002 wildfire, 365 the IC maps show high values of the index also near the channel heads of the two main branches of the Rio 366 Toro (Fig. 6B). Apparently, the IC remained constant also for 2015 (Fig. 6C) and 2016 (Fig. 6D) maps. 
Although the multi-temporal assessment points out similar patterns of high and low IC in all the scenarios, the degree of linkage between slopes and channel network, enhanced in post-wildfire scenarios.

371 To emphasize the IC changes, the difference of IC (DoIC) between post-wildfire and pre-wildfire scenarios was computed for the two events. The DoIC maps are presented in Figure 7, where darker the colour, higher the increase in IC after the wildfire. It is important to mention that the classification of the two maps varies according to the value range of each map, except for the decrease class, since this class consistently refers to negative values. The 2003-2002 DoIC map (Fig. 7A) shows a clear upward trend, with a mean value of $1.07( \pm 0.38)$ and observed minimum and maximum variation of -1.56 and 2.88 respectively. Low, moderate and high increase of IC values cover $24.1 \%, 51.8 \%$ and $23.4 \%$ of the whole catchment, with mean values of $0.57,1.11,1.52$. Notably, high positive DolC values are detectable near the junction of the two main streams and in the proximity of areas of convergence of flows and channel heads. On the contrary, areas showing decreasing IC values are covering the $0.7 \%$ of the catchment (mean -0.28$)$.

After the second wildfire, the 2016-2015 DolC map (Fig. 7B) shows again an upward trend but with a lower mean values than the first event for the overall catchment $(0.53 \pm 0.22)$ and DolC classes $(-0.11,0.20,0.51$, 0.75). Nonetheless, the representativeness of each DolC class is: decrease areas are $1.3 \%$; low increase areas are $20.7 \%$; moderate increase areas are $40 \%$ and high increase $38 \%$. The spatial arrangement of the classes shows high increase IC areas close to the stream network and they are mainly located in the central part of the basin rather than at the channel heads. Decreasing IC areas are instead confined to small spots near the outlet and on the high and flat areas along the southern border, already characterized by low IC in the pre-wildfire scenario (Fig. 6C). 
The comparison between fire severity and sediment connectivity can help to shed light on the effect of how a wildfire can affect sediment connectivity. As expected, from a first qualitative assessment of the maps, the spatial patterns are very similar. Areas of lower DolC (decrease and low increase) located where the fire severity is lower (unburned and low severity) and areas of higher DolC (moderate and high increase) where the fire severity is higher (moderate and high severity).

Quantitatively, the overlap between the connectivity and severity component is expressed as the area (\%) of DolC class that partly covers the corresponding fire severity class (Table 3). Particular attention was given to the diagonal values, representing the overlap of counterparts. After the first wildfire, the $84.7 \%$ overlap confirms what previously observed between the two maps: high DolC spatial patterns extensively corresponds to high fire severity.

\section{\#\#\# TABLE 3 \#\#\#}

On the contrary, the correspondence between decrease IC areas and unburned areas is only the $24.9 \%$. Indubitably, the huge extent of high severity class causes most of the DoIC areas to be greatly overlapped by it. Even the decrease IC areas, in fact, are constituted by high severity areas for the $40.8 \%$. After the second wildfire, the highest correspondence is between decrease IC areas and unburned areas (Table 4), with an overlap of $94.5 \%$, which confirms what can be seen in the maps. Still, high overlap is visible among higher classes, i.e. moderate-moderate, high-high, with a $54.3 \%$ and $43.4 \%$ respectively.

Figure 8A shows the DolC distributions for the period 2003-2002 and Figure 8B the DolC distributions for the 2016-2015 time window. The medians of DolC values according to the four severity classes were $0.68,0.91$, $4191.05,1.19$ for the first event and $0.22,0.49,0.62$ and 0.70 for the second one, respectively. While considering 420 the second wildfire the results suggest that higher the fire severity and higher is the increase in IC values, in the 2002 event, the correlation is less clear due to the higher data dispersion. However, in both cases, the distributions of each group were found statistically different among each other ( $\mathrm{KW}$ test, $p$-value $<0.001$ ). 
The distribution of DoIC values, fire severity and topography is presented in Figure 9, where the three most significant topographic variables (Table 2) are used.

428 Generally, among all fire severity classes, the higher DolC values correspond to high severities but, again, the DolC values for the first event show higher data dispersion than the second. After the 2002 wildfire, the higher DoIC values are found in areas facing North, whereas the lowest values in areas facing West, with both statistically different (KW test, $p$-value $<0.001$ ) from the others (Fig.9A). The DolC values for the 2015 wildfire instead do not show a clear pattern among the aspects and there is no statistical difference (KW test, $p$-value $>0.001$ ) between North and West for the high fire severity classes (9B). The interaction with slope position for the first event (Fig.9C) shows that the highest and lowest DoIC interquartile ranges are observed for the lower slope positions, in which the DoIC distributions are also the only statistically different from the others.

437 This result suggests that, when a fire occurs, slope positions at intermediate elevation characterized by low slopes greatly enhanced fire severity and consequently the increase in IC. On the other hand, without any disturbance, this type of position promotes vegetation development. In the second case, again unburned areas located on lower slopes show the lowest DolC values but the highest increase characterizes the areas of high severity on upper slopes (Fig. 9D).

Finally, the variation of DoIC as function of slope indicates that a higher increase in IC values is detected at minor slope degrees in the first event (Fig. 9E) but, the opposite trend, in the second event (Fig. 9F).

\#\#\# FIGURE 9 \#\#\#

\section{DISCUSSION}

448 In the Rio Toro catchment, two major wildfires occurred in 13 years, causing severe changes to the land 449 cover and vegetation structures. The assessment of fire severity showed that most of the catchment was hit 
450 by wildfire of moderate and high severity. Indeed the first wildfire strongly affected the vegetation community 451 of the catchment and surrounding territory, as observed by other authors (Comiti et al., 2008; Iroumè et al., 452 2015; Assal et al., 2018; Mazzorana et al., 2019; Picco et al., in review). On the other hand, the second 453 wildfire showed lower severity values but similar spatial patterns, for instance, demonstrated by the 454 persistence of unburned areas at the northern and southern borders. The result of lower severity after 455 previous high severity events is in contrast with some studies developed in the south-west of the US (Holden 456 et al., 2010; Parks et al., 2014) but shared by Stevens-Rumann et al. (2016), who found this divergence as 457 caused by slower vegetation recover response after the prior disturbance. In our study area, in fact, the first 458 fire had much more fuel's availability compared to the second one, which occurred just after 13 years. In the 459 assessment of the 2015 second event, the use of a relative vegetation index, such the RdNBR, helped to 460 avoid the bias of the low amount of 2015 pre-fire vegetation caused by the first wildfire. However, the 461 difference between the two fire severity maps could be caused by the classification procedure, which relies 462 upon field surveys carried out four years after the second wildfire, or by the RdNBR values used in the 463 polynomial function and associated to total changes after both wildfires (RdNBR 2016-2002, see section 3.3). 464 The resulting $62 \%$ of classification accuracy, obtained from the measured and predicted severity, can affect 465 model outcomes. In the end, the choice of an appropriate spectral index for fire severity assessment is 466 fundamental. We selected the SWIR-based NBR, for its higher sensitivity to fire damages and post467 disturbance forest structure recovery (Pickell et al., 2016). Although Ortíz-Rodríguez et al. (2019) found good 468 classification agreement using the NDVI for fire severity assessment, the peculiar condition of fire recurrence 469 in the Rio Toro catchment led us to avoid indexes with lower disturbance response, such as the NDVI, which 470 proved to overestimate recovery rates (Schroeder et al., 2011; Morresi et al., 2019).

471 As proved in several case studies (Iniguez et al., 2008; Oliveras et al., 2009; Estes et al., 2017), topography 472 plays a fundamental role in the distribution patterns of burned areas. In the Rio Toro catchment, slope more 473 than other variables showed correlation to fire severity. Nonetheless, other fire drivers like wind, temperature 474 and fuel's characteristics must not be neglected for their growing importance in the context of climate change 475 and particularly in south-central Chile, where a strong decrease in precipitation is expected in the next years 476 (CONAMA, 2006; Úbeda and Sarricolea, 2016). 
The analysis of sediment connectivity highlighted a general increase of IC values after the wildfires, with high

478 IC increase mainly located in the headwaters in 2002 and the central part of the catchment in 2015. This

479 suggests that, after the second wildfire, potential loose sediment could have higher chances to enter the channel network and being transported downstream thanks to their proximity to the outlet.

Moreover, the DolC average values observed for the two wildfires, reflected the difference in fire severity: higher overall increase of IC values after the first wildfire than the second one (i.e. higher DoIC values for the 2002 disturbance). However, the lower increase observed in the second scenario could be associated with the estimation of the Manning's $n$, which primarily drives the IC in our study case. While for the fire severity assessment we made use of a relative index for burn detection, the IC calculation was based on the IFZ, which enhances the detection of forest recovery and thereby higher impedance to sediment fluxes. Hence, the difference in the DolC between the two events can be associated to: i) lower severity of the 2015 wildfire, ii) IFZ overestimation of the 2015 pre-fire vegetation cover iii) actual fast recovering rate in the AraucariaNothofagus forest after the first wildfire. The last hypothesis is also supported by field evidence. Just four years after the 2015 wildfire, shrubs species such the endemic Chusquea spp. re-occupied large patches of the study area and blocking many pathways. Therefore, in our study area, shrubs might represent the conjunction between the ecological and geomorphological response, since their encroachment can enhance rapidly the storage capacity and reduce sediment connectivity.

Despite the overall higher increase of IC after the 2002 wildfire, the results demonstrated stronger correlation between fire severity and sediment connectivity after the 2015 event. The first wildfire was characterized by poorer spatial patterns overlap due to the huge extent of the high fire severity class: contrary to DolC, the fire severity variable was almost saturated by the highest class. In addition, IC values showed higher data dispersion than for the second event. The cause of such different variability of IC values found after the two events may be attributable to the different degree of land cover heterogeneity in the pre-2002 scenarios. While before 2002 the catchment showed high variability of forest structures, hence high fuel vegetation heterogeneity, before the 2015 the vegetation was far more homogeneous. Since the severity of 2002 disturbance was high on the majority of the study area, successional dynamics driving the vegetation 
504 and herb layers) and the short time period between the two disturbances was not enough to differentiate fuel load and structure among different sites. given the passage of the first fire

506 The application of the IC permitted to capture the main changes in possible sediment sources, routes and 507 deposits at the catchment scale. In post-disturbance scenarios the IC has been used to summarize the sediment dynamic changes but, according to the characteristics of the disturbance and environment, different W factors would have been used. In forested mountain catchments, neither the standard Roughness Index (Cavalli et al., 2013) nor the C-factor are suggested since they are more focused on applications to high altitude headwater catchments characterized by lack of forest cover and agricultural catchments where the role of crop management systems in terms of soil loss is pivotal. On the contrary, Manning's $n$ is becoming much more used (e.g. Persichillo et al., 2018; Llena et al., 2019), especially with high land-use heterogeneity. Nonetheless, the Manning's $n$ causes low distribution in $\mathrm{W}$ factor values and requires tabled data. We tried to overcome the first issue, which has been proved to impact negatively the IC (Zanandrea et al., 2020), by normalizing the $\mathrm{W}$ factor. To avoid the mere use of tabled data, we implemented a methodology that exploits field observations and remote sensing data in order to adapt the $\mathrm{W}$ factor to specific post-disturbance conditions without yielding too much subjectivity. Zanandrea et al. (2020), offered an alternative W factor that properly preserved adimensionality and emphasized the role of forests but without the chance to adjust the methodology to dynamic environments. Therefore, with this work we tried to progress toward the standardization of the $\mathrm{W}$ factor without neglecting the importance of field data and considering the role of regeneration in post-wildfire scenarios by using the IFZ over the NDVI.

The choice of the appropriate $\mathrm{W}$ factor also depends on the data availability as well as temporal and spatial scales. For instance, Mishra et al. (2019) calculated the impedance according to a simple remote assessment of vegetation, based on the C-factor and NDVI, to study major sediment connectivity patterns in a large basin; Estrany et al. (2019), used the traditional Roughness Index to study plot-scale vegetation-sediment structures in micro-catchments; Kalantari et al. (2017), proposed a W factor based on runoff generation potential, having different land use and group of soil types within the lowland study area.

529 The compound analysis of fire severity and sediment connectivity highlighted the main areas of interest, where presumably the land cover changes were exacerbated and so characterized by high severity and high

531 increase in IC. It is worth mentioning that the increase of IC at the pixel scale is not the mere result of the 
adopted weighting factor but it is also the outcome of the propagation of changes due to land cover variations in the catchment. Considering also the intrinsic characteristics of the catchment, it was possible to identify 534 where the IC increased the most for each fire severity class. Therefore, it appeared that during the first wildfire, lower slope positions and on gentle slopes facing North promoted fire severity; hence the IC. These results can be seen partially in contradiction with literature data. In fact, while on northern aspects, in the southern hemisphere, temperature and fuel conditions are usually suitable for increasing wildfire occurrence and severity, lower slope positions on gentle slopes are not (Carmo et al., 2011; Estes et al., 2017). These areas were actually covered by Nothofagus spp., species that do not present resistance traits and can be deeply affected even at intermediate fire intensity (Gonzalez et al., 2005). On upper slope positions the Araucaria stands were greatly damaged when high-intensity crown fires affected the stand, while with lower intensity the severity was lesser due to the resistance traits of the species, such as thick bark and a crown displaced several meters above the ground in mature trees (Burns 1993; Gonzalez et al., 2010).

544 To provide useful information for management decisions, the results of the present study should be 545 considered as a whole. Hence, the prioritization of catchment areas after wildfires would rely on: i) the fire 546 severity maps, describing where overland flow, soil erosion and sediment yields could be suddenly boosted, 547 ii) the most recent IC map, showing where there is higher degree of connectivity to sensitive targets, and iii) 548 the DolC map, demonstrating where the connectivity suddenly increased. However, in post-fire scenarios falling dynamics of damaged and standing dead trees can last for decades and, depending on species and snag size (Marzano et al., 2012; Molinas et al., 2017), they can either provide elements able to enhance microsite for regeneration on the slopes (Marzano et al., 2013) or be recruited as large wood in river systems. (Benda and Sias, 2003).

553 Finally, it is important to point out that the IC offers only semi-quantitative information of the potential sediment 554 transfers, while for accurately predicting sediment displacement and dynamics, a different analysis considering also other driving factors is indeed required. Notably, in post-wildfire scenarios these factors are 556 associated with the reduction of soil infiltration parameters, changes in soil physicochemical properties and 557 the presence of ashes, which are all responsible of alteration in runoff and sediment transfer (Shakesby, 558 2011). Considering also these variables would have required dedicated field campaigns and would have 559 moved simple approaches based on geomorphometric indices to more complex and sophisticated models 
with all the uncertainties related to the different variables estimations. Aware of all the limitations of our approach, in the present work, the aforementioned factors have been overlooked to restrict the variables involved and focus on the topography and land cover based ones. We used land cover changes as the only proxy for sediment impedance. This choice is justified by the lack of multi-temporal DEMs and by the absence of major morphological changes occurred between the two wildfires. In addition, altough our work exploited open-source data, which can be used to replicate and standardize the procedure in different post-disturbance contexts, much attention has been paid to their spatial resolution to consider the most appropriate scale for the results. Sediment connectivity outcomes can cause serious misinterptrations if there is an imbalance between the scale of data and objectives. According to Cantreul et al. (2018), $1 \mathrm{~m}$ is the best resolution for the IC application in a crop-managed watershed of $1.24 \mathrm{~km}^{2}$, while López-Vicente and Álvarez (2018) suggested a $0.20 \mathrm{~m}$ resolution to study soil displacement in a $0.274 \mathrm{~km}^{2}$ area. Different resolutions have been chosen in other contexts. It is our opinion that the choice of the spatial resolution has to consider the objectives of the sediment connectivity analysis and, turning this concept over, the available spatial resolution poses a limit to geomorphometric analysis that could be carried out. High-resolution DEMs are fundamental to investigate fine-scale processes (Cantreul et al., 2018; López-Vicente and Álvarez, 2018; Tarolli et al., 2019) and allows to derive important parameters as local surface roughness to characterize sediment dynamics at these scales Different and simplified approaches can be devised when only coarse DEMs are available and the aim of the study is focused on large scale processes as coarse material sediment transport

578 in large catchments. Accordingly, we found that a Global DEM at a $12.5 \mathrm{~m}$ resolutions suitable for detecting major spatial patterns of IC in an Andean catchment. The proposed workflow could be effectively applied to investigatepost-disturbance scenarios in other areas where high-resolution data are not available.

\section{CONCLUSIONS}

584 The interaction between wildfire severity and sediment connectivity has been presented in order to map the 585 ecological and geomorphological effects of multiple wildfires on the Rio Toro catchment (Chile). The 
586 proposed method combines field data and open source satellite imagery to identify the spatial patterns of 587 sediment connectivity variations driven by two subsequent wildfires.

588 In the study catchment, the wildfire severity assessment pointed out the different severity patterns between 589 the two events. The 2002 wildfire affected the $91 \%$ of the catchment, of which almost $70 \%$ was classified as 590 high severity, while the 2015 wildfire significantly affected the $76 \%$, of which only the $23 \%$ was classified as 591 high severity. These results are mainly ascribed to the different fuel's availability and land cover heterogeneity 592 between the two pre-fire scenarios. The sediment connectivity maps showed large areas of high IC increase 593 located at the headwaters, after the first wildfire, and in the central part of the catchment after the second 594 wildfire. The IC values varied according to the difference in fire severity: catchment's average increase of 5951.07 after the first wildfire, 0.53 after the second one. However, the response of IC to fire severity was less 596 evident in the first event, being the overlap between fire severity and DolC spatial patterns leveled off by the vastity of high severity areas. Therefore, the relationship between wildfire severity and sediment connectivity was weaker when the severity classification approached saturation.

599 The methodology proposed represents a good compromise between the reliability of the results and the 600 limited availability of high resolution data in inaccessible areas. The integration between geomorphometric 601 analysis based on open-source satellite products and field work can definitely promote sediment connectivity 602 spatial patterns characterization and the study of its relationship with wildfire severity, although more efforts 603 can be made to improve the classification accuracy. In addition, the computation of a normalized W factor 604 helped to better capture the main effects of the wildfires on the IC thanks to appropriate land cover change 605 detection indices.

606 Finally, we suggest that further research in this field may consider also the integration of soil properties in the 607 analysis, which be source of significant alterations of the sediment impedance, as well as the use of multiple 608 topographic surveys if available.

609

610 ACKNOWLEDGMENT 
This study was developed within the framework of projects FONDECYT 1170413 and CONICYT-ITAL17004.

613 We would like to thank the two anonymous reviewers for their valuable feedbacks and the associate editor 614 Paulo Pereira for handling the manuscript.

\section{REFERENCES}

616

617

Arcement, G. J., Schneider, V. R. 1989. Guide for Selecting Manning 's Roughness Coefficients for Natural Channels and Flood Plains United States Geological Survey Water-Supply Paper 2339. United States

ASF, 2019. ASF - Alaska Satellite Facility. Available at. https://www.asf.alaska.edu/.

621

622

ASF DAAC 2009, ALOS PALSAR_AP_16411_FBS_F6410_RT1_Radiometric _Terrain_ corrected_high_res: Includes Material @ JAXA/METI 2009. Accessed through ASF DAAC 30 November 2018. DOI: https://doi.org/10.5067/Z97HFCNKR6VA.

Assal, T. J., González, M. E., Sibold, J. S. 2018. Burn Severity Controls on Postfire Araucaria-Nothofagus Regeneration in the Andean Cordillera. Journal of Biogeography 45(11):2483-2494.

Banskota, A., Kayastha, N., Falkowski, M. J., Wulder, M. A., Froese, R. E., White J. C. 2014. Forest Monitoring Using Landsat Time Series Data: A Review. Canadian Journal of Remote Sensing 40(5):362-384.

Benavides-Solorio, J., MacDonald, L. H. 2001. Post-Fire Runoff and Erosion from Simulated Rainfall on Small Plots, Colorado Front Range. Hydrological Processes 15(15):2931-2952.

Benda, L. E., Sias, J. C. 2003. A Quantitative Framework for Evaluating the Mass Balance of In-Stream Organic Debris. Forest Ecology and Management 172(1):1-16.

Borselli, L., Cassi, P., Torri, D. 2008. Prolegomena to Sediment and Flow Connectivity in the Landscape: A GIS and Field Numerical Assessment. Catena 75(3):268-277.

Bowman, D. M. J. S., Moreira-Muñoz, A., Kolden, C.A., Chávez, R.O., Muñoz, A. A., Salinas, F., González- 

drivers and impacts of the globally extreme 2017 Chilean fires. Ambio 48:350-362.

Bracken, L. J., Crooke, J. 2007. The Concept of Hydrological Connectivity and its Contribution to Understanding Runoff-Dominated Geomorphic Systems. Hydrological Processes 21:1749-1763.

Brogan, D. J., MacDonald, L. H., Nelson, P. A., Morgan, J. A. 2019. Geomorphic Complexity and Sensitivity in Channels to Fire and Floods in Mountain Catchments. Geomorphology 337:53-68.

Brunsden, D., Thornes, J.B. 1979. Landscape sensitivity and change. Transactions of the Institute of British Geographers 4:463-484.

Burns B.R. 1993. Fire-Induced Dynamics of Araucaria araucana-Nothofagus antarctica Forest in the Southern Andes. Journal of Biogeography 20:669-685.

Cantreul, V., Bielders, C., Calsamiglia, A., Degré, A., 2018. How pixel size affects a sediment connectivity index in central Belgium. Earth Surf. Process. Landf. 43 (4), 884-893. https://doi.org/10.1002/esp.4295.

Carmo, M., Moreira, F., Casimiro, P., Vaz, P. 2011. Land Use and Topography Influences on Wildfire Occurrence in Northern Portugal. Landscape and Urban Planning 100(1-2):169-176.

Cavalli, M., Trevisani, S., Comiti, F., Marchi, L. 2013. Geomorphometric Assessment of Spatial Sediment Connectivity in Small Alpine Catchments. Geomorphology 188:31-41.

Cavalli, M., Vericat, D., Pereira, P. 2019. Mapping Water and Sediment Connectivity. Science of the Total Environment 673:763-767.

Cembrano, J., Lara, L. 2009. The Link between Volcanism and Tectonics in the Southern Volcanic Zone of the Chilean Andes: A Review. Tectonophysics 471(1-2):96-113.

Certini, G. 2005. Effects of fire on properties of forest soils: a review. Oecologia 143:1-10, 657 doi:10.1007/s00442-004-1788-8

Chartin, C., Evrard, O., Laceby, J. P., Onda, Y., Ottlé, C., Lefèvre, I., Cerdan, O. 2017. The impact of 659 typhoons on sediment connectivity: lessons learnt from contaminated coastal catchments of the 

https://doi.org/10.1002/esp.4056.

Chu, T., Guo, X., Takeda, K. 2016. Remote Sensing Approach to Detect Post-Fire Vegetation Regrowth in Siberian Boreal Larch Forest. Ecological Indicators 62:32-46

Comiti F, Andreoli, A., Lenzi, M. A., Mao, L. 2008. Wood storage in three mountain streams of the Southern Andes and its hydro-morphological effects. Earth Surface Processes and Landforms 33:244-262

CONAF, 2019. Estadísticas - Resumen Regional Ocurrencia (Número) y Daño (Superficie Afectada) por Incendios Forestales 1977 - 2019.

CONAMA, 2006. Estudio de la variabilidad climática en Chile para el siglo XXI. Informe Final. Chile. CONAMA, Santiago.

Crema, S., Cavalli, M. 2018. SedlnConnect: a stand-alone, free and open source tool for the assessment of sediment connectivity. Computers and Geosciences 111: 39-45.

DeBano, L. F., Neary, D. G., Ffolliott, P. F. 1998. Fire's effects on ecosystems. New York: John Wiley and 674 Sons, Inc. 333 p.

EarthExplorer, 2019. U.S. Geological Service EarthExplorer. Available at. https:// earthexplorer.usgs.gov/.

Estes, B. L., Knapp, E. E., Skinner, C. N., Miller, J. D., Preisler, H. K. 2017. Factors Influencing Fire Severity under Moderate Burning Conditions in the Klamath Mountains, Northern California, USA. Ecosphere $8(5)$.

Estrany, L., Ruiz, M. , Calsamiglia, A., Carriquí, M., García-comendador, J. 2019. Sediment Connectivity Linked to Vegetation Using UAVs: High-Resolution Imagery for Ecosystem Management. Science of the Total Environment 671:1192-1205.

Fryirs, K. 2013. (Dis)Connectivity in Catchment Sediment Cascades: A Fresh Look at the Sediment Delivery 683 Problem. Earth Surface Processes and Landforms 38(1):30-46. 
Fuenzalida, H. 1965. Geografía Económica de Chile. CORFO, Santiago de Chile.

685

686

687

Gay, A., Cerdan, O., Mardhel, V., Desmet, M. 2016. Application of an index of sediment connectivity in a lowland area. Journal of Soils and Sediments, 16(1):280-293. https://doi.org/10.1007/s11368-015$1235-\mathrm{y}$.

Gesch, D.B., Oimoen, M.J., Evans, G.A., 2014. Accuracy assessment of the U.S. Geological Survey National Elevation Dataset, and comparison with other large area elevation datasets SRTM and ASTER. U.S. Geological Survey Open File Report 2014-1008.

González, M. E., Veblen, T. T., Sibold, J. S. 2005. Fire History of Araucaria-Nothofagus Forests in Villarrica National Park, Chile. Journal of Biogeography 32(7):1187-1202.

González, M. E, Veblen, T.T., Sibold, J. 2010. Influence of fire severity on stand development of Araucaria araucana - Nothofagus pumilio stands in the Andean cordillera of south-central Chile. Austral Ecology 35:597-615.

Guisan, A., Weiss, S. B., Weiss, A. D. 1999. GLM versus CCA spatial modeling of plant species distribution. Plant Ecology 143: 107-122

Gunckel, L. H. 1948. La floracion de la quila y del colihue en la Araucania. Ciencia e Investigacion 4: 91-95.

Hallema, D. W., Sun, G., Caldwell, P., Robinne, FN., Bladon, K. D., Norman, S., Liu., Y., Cohen, E.C., McNulty, S. 2019. Wildland fire impacts on water yield across the contiguous United States. Gen. Tech. Rep. SRS-238. Asheville, NC: U.S. Department of Agriculture Forest Service, Southern Research Station.109p.

Heckmann, T., Cavalli, M., Cerdan, O., Foerster, S., Javaux, M., Lode, E., Smetanova, A., Vericat, D., Brardinoni, F. 2018. Indices of sediment connectivity: opportunities, challenges and limitations. EarthScience Reviews 187:77-108. https://doi.org/10.1016/J.EARSCIREV.2018.08.004.

Holden, Z. A., Morgan, P., Hudak, A. T. 2010. Burn Severity of Areas Reburned by Wildfires in the Gila National Forest, New Mexico, USA. Fire Ecology 6(3):77-85. 
708

Huang, C., Goward, S. N., Masek, J. G., Thomas, N., Zhu, Z., Vogelmann, J. E. 2010. An Automated Approach for Reconstructing Recent Forest Disturbance History Using Dense Landsat Time Series Stacks. Remote Sensing of Environment 114(1):183-98.

Iniguez, J. M., Swetnam, T. W., Yool, S. R. 2008. Topography Affected Landscape Fire History Patterns in Southern Arizona, USA. Forest Ecology and Management 256(3):295-303.

Iroumé, A., Mao, L., Andreoli, A., Ulloa, H., Ardiles, M. P. 2015. Large Wood Mobility Processes in Low-Order Chilean River Channels. Geomorphology 228:681-93.

Kalantari, Z., Cavalli, M., Cantone, C., Crema, S., Destouni, G. 2017. Flood Probability Quantification for Road Infrastructure : Data-Driven Spatial-Statistical Approach and Case Study Applications. Science of the Total Environment 581-582:386-98.

Key, C. H., Benson, N. C. 2006. Landscape Assessment (LA). In: Lutes, D. C., Keane, R. E., Caratti, J. F., Key, C. H., Benson, N. C., Sutherland, S., Gangi, L. J. 2006. FIREMON: Fire effects monitoring and inventory system. Gen. Tech. Rep. RMRS-GTR-164-CD. Fort Collins, CO: U.S. Department of Agriculture, Forest Service, Rocky Mountain Research Station. p. LA-1-55.

Larsen, I. J., MacDonald, L. H., Brown, E., Rough, D., Welsh, M.J., Pietraszek, J.H., Libohova, Z., BenavidesSolorio, J., Schaffrath, K. 2009. Causes of Post-Fire Runoff and Erosion: Water Repellency, Cver, or Soil Sealing? Soil Science Society of America Journal 73(4): 1393-1407.

Lizaga, I., Quijano, L., Palazón, L., Gaspar, L., Navas, A. 2017. Enhancing Connectivity Index to Assess the Effects of Land Use Changes in a Mediterranean Catchment. Land Degradation and Development 675: 663-675. https://doi.org/10.1002/ldr.2676.

Llena, M., Vericat, D., Cavalli, M., Crema, S., Smith, M. W. 2019. The effects of land use and topographic changes on sediment connectivity in mountain catchments. Science of the Total Environment 660:899912. https://doi.org/10.1016/j.scitotenv.2018.12.479.

López-Vicente, M., Álvarez, S., 2018. Influence ofDEM resolution on modelling hydrolog- ical connectivity in a complex agricultural catchment with woody crops. Earth Surf. Process. Landf. 43 (7), 1403-1415. 
https://doi.org/10.1002/esp.4321.

734

735

736

737

738

739

740

741

742

743

744

745

746

747

748

749

750

751

752

753

754

755

756

757

López-Vicente, M., Ben-Salem, N. 2019. Computing Structural and Functional Flow and Sediment Connectivity with a New Aggregated Index: A Case Study in a Large Mediterranean Catchment. Science of The Total Environment 651:179-191.

Martini, L., Picco, L., Iroumé, A., Cavalli, M. 2019. Sediment Connectivity Changes in an Andean Catchment Affected by Volcanic Eruption. Science of The Total Environment 692:1209-1222.

Marzano, R., Lingua, E., Garbarino, M. 2012. Post-fire effects and short-term regeneration dynamics following high-severity crown fires in a Mediterranean forest. iForest - Biogeosciences and Forestry 5 : 93-100.

Marzano, R., Garbarino, M., Marcolin, E., Pividori, M., Lingua, E. 2013. Deadwood anisotropic facilitation on seedling establishment after a stand-replacing wildfire in Aosta Valley (NW Italy). Ecological Engineering 51:117-122.

Mazzorana, B., Picco, L., Rainato, R., Iroumé, A., Ruiz-Villanueva, V., Rojas, C., Valdebenito, G., IribarrenAnacona, P., Melnick, D. 2019. Cascading processes in a changing environment: Disturbances on fluvial ecosystems in Chile and implications for hazard and risk management. Science of The Total Environment 655:1089-1103. https://doi.org/10.1016/j.scitotenv.2018.11.217

Messenzehl, K. Hoffmann, T., Dikau, R. 2014. Sediment Connectivity in the High-Alpine Valley of Val Müschauns, Swiss National Park - Linking Geomorphic Field Mapping with Geomorphometric Modelling. Geomorphology 221:215-29.

Miller, J. D., Knapp, E. E., Key, C. H., Skinner, C. N., Isbell, C. J., Creasy, R. M., Sherlock, J.W. 2009. Calibration and Validation of the Relative Differenced Normalized Burn Ratio (RdNBR) to Three Measures of Fire Severity in the Sierra Nevada and Klamath Mountains, California, USA. Remote Sensing of Environment 113(3):645-56.

Miller, J. D., Thode, A. E. 2007. Quantifying Burn Severity in a Heterogeneous Landscape with a Relative Version of the Delta Normalized Burn Ratio (DNBR). Remote Sensing of Environment 109(1):66-80. 
Mishra, K., Sinha, R., Jain, V., Nepal, S., Uddin, K. 2019. Towards the Assessment of Sediment Connectivity in a Large Himalayan River Basin. Science of the Total Environment 661:251-65.

Molinas C., Leverkus A., Marañón-Jiménez S., Castro J. 2017. Fall rate of burnt pines across an elevational gradient in a Mediterranean mountain. European Journal of Forest Research 136(3) doi: $10.1007 / \mathrm{s} 10342-017-1040-9$

Morresi, D., Vitali, A., Urbinati, C., Garbarino, M. 2019. Forest Spectral Recovery and Regeneration Dynamics in Stand-Replacing Wildfires of Central Apennines Derived from Landsat Time Series. Remote Sensing 11(3):308.

Neary, Daniel G.; Ryan, Kevin C.; DeBano, Leonard F., 2005. Wildland fire in ecosystems: effects of fire on soils and water. Gen. Tech. Rep. RMRS-GTR-42-vol.4. Ogden, UT: U.S. Department of Agriculture, Forest Service, Rocky Mountain Research Station. 250 p.

Oliveras, I., Gracia, M, , Moré, G., Retana, J. 2009. Factors Influencing the Pattern of Fire Severities in a Large Wildfire under Extreme Meteorological Conditions in the Mediterranean Basin. International Journal Of Wildland Fire 18(7):755-764.

Ortíz-rodríguez, A. J., Muñoz-robles, C., Borselli, L. 2019. Changes in connectivity and hydrological efficiency following wildland fires in Sierra Madre Oriental, Mexico. Science of The Total Environment 655:112128. https://doi.org/S0048969718345923

Parks, S. A., Dillon, G. K., Miller, C. 2014. A New Metric for Quantifying Burn Severity: The Relativized Burn Ratio. Remote Sensing 6(3):1827-1844.

Parks, S. A., Miller, C., Nelson, C. R., Holden, Z. A. 2014. Previous Fires Moderate Burn Severity of Subsequent Wildland Fires in Two Large Western US Wilderness Areas. Ecosystems 17(1):29-42.

Persichillo, M. G., Bordoni, M., Cavalli, M., Crema, S., Meisina, C. 2018. The role of human activities on sediment connectivity of shallow landslides. Catena 160: 261-274. https://doi.org/10.1016/j.catena.2017.09.025

Pickell, P. D., Hermosilla, T., Frazier, R. J., Coops, N. C., Wulder, M. A. 2016. Forest Recovery Trends 

Sensing 37(1):138-149.

785

Rainato, R., Picco, L., Cavalli, M., Mao, L., Neverman, A.J., Tarolli, P. 2018. Connecting climate conditions, sediment sources and sediment transport in an alpine basin. Land Degradation and Development 29(4): 1154-1166, doi: 10.1002/ldr.2813.

Roy, D. P., Kovalskyy, V., Zhang, H. K., Vermote, E. F., Yan, L., Kumar, S. S., Egorov, A. 2016. Characterization of Landsat-7 to Landsat-8 Reflective Wavelength and Normalized Difference Vegetation Index Continuity. Remote Sensing of Environment 185:57-70.

RStudio Team 2016. RStudio: Integrated Development for R. RStudio, Inc., Boston, MA URL http://www.rst udio.com/.

Schroeder, T.A., Wulder, M. A., Healey, S. P., Moisen, G. G. 2011. Mapping Wildfire and Clearcut Harvest Disturbances in Boreal Forests with Landsat Time Series Data. Remote Sensing of Environment 115(6):1421-1433.

Shakesby, R. A., Doerr, S.H. 2005. Wildfire as a hydrological and geomorphological agent. Earth-Science Reviews 74:269-307.

Shakesby, R. A. 2011. Post-Wildfire Soil Erosion in the Mediterranean: Review and Future Research Directions. Earth-Science Reviews 105(3-4):71-100.

Singh, M., Sinha, R. 2019. Evaluating Dynamic Hydrological Connectivity of a Floodplain Wetland in North Bihar, India Using Geostatistical Methods. Science of the Total Environment 651:2473-2488.

Stevens-Rumann, C. S., Prichard, S. J., Strand, E. K., Morgan, P. 2016. Prior Wildfires Influence Burn Severity of Subsequent Large Fires. Canadian Journal of Forest Research 46(11):1375-1385.

Swanson, F.J., 1981. Fire and geomorphic processes. in: Mooney, H.A., Bonnicksen, T.M., Christiansen, N.L., Lotan, J.E., Reiners, W.A. (Eds.), Fire Regime and Ecosystem Properties, United States Department of Agriculture, Forest Service, General Technical Report WO vol. 26. United States Government Planning Office, Washington, DC, pp. 401-421. 
808 809

810 811

812 813

Tarboton, D.G. 1997. A New Method for the Determination of Flow Directions and Upslope Areas in Grid Digital Elevation Models. Water Resources Research 33, 309-319.

Tarolli, P., Cavalli, M., Masin, R. (2019). High-resolution morphologic characterization of conservation agriculture. Catena 172: 846-856.

Trevisani, S., Cavalli, M. 2016. Topography-Based Flow-Directional Roughness: Potential and Challenges. Earth Surface Dynamics 4(2):343-358.

Úbeda, X., Sarricolea, P. 2016. Wildfires in Chile: A Review. Global and Planetary Change 146:152-161.

Veblen, T.T., Donoso, C., Schlegel, F.M., Escobar, B. 1981. Forest dynamics in South-Central Chile. Journal of Biogeography 8(3): 211-247

Veblen, T. T. 1982. Regeneration Patterns in Araucaria araucana Forests in Chile. Journal of Biogeography $9(1): 11-28$.

Vieira, D.C.S., Fernandez, C., Vega, J. A., Keizer, J.J. 2015. Does soil burn severity affect the post-fire runoff and interrill erosion response? A review based on meta-analysis of field rainfall simulation data. Journal of Hydrology 523:452-464.

Williams, C. J., Pierson, F. B., Robichaud, P. R., Al-Hamdan, O. Z., Boll, J., Strand, E. K. 2016. Structural and Functional Connectivity as a Driver of Hillslope Erosion Following Disturbance. International Journal of Wildland Fire 25(3):306-321.

Wischmeier, W.H., Smith, D.D. 1978. Predicting Rainfall Erosion Losses a Guide to Conservation Planning. Predicting rainfall erosion losses - a guide to conservation planning, USDA, Science and Education Administration.

Wohl, E., Brierley, G., Cadol, D., Coulthard, T.J., Covino, T., Fryirs, K.A., Grant, G. Hilton, R.G., Lane, S.N., Magilligan, F.J., Meitzen, K.M., Passalacqua, P., Poeppl, R.E., Rathburn, S.L., Sklar, L.S. 2019. Connectivity as an Emergent Property of Geomorphic Systems. Earth Surface Processes and Landforms 44: 4-26, https://doi.org/10.1002/esp.4434. 
832 Wohl, E., Scott, D. N. 2017. Transience of Channel Head Locations Following Disturbance. Earth Surface $833 \quad$ Processes and Landforms 42(7):1132-1139.

834 Woods, S.W., Balfour, V.N., 2008. The effect of ash on runoff and erosion after a severe forest wildfire, 835 Montana, USA. International Journal of Wildland Fire 17, 535-548.

836 Young, N. E., Anderson, R. S., Chignell, S. M., Vorster, A. G., Lawrence, R, Evangelista, P, H. 2017. A 837 Survival Guide to Landsat Preprocessing. Ecology 98(4):920-932.

838 Zanandrea, F., Michel, G.P., Kobiyama, M. 2020. Impedance Influence on the Index of Sediment Connectivity 839 in a Forested Mountainous Catchment. Geomorphology 351:106962.

840

841

842 